\title{
Global Climate Change Related Zoonotic ID and Impact on Global Health Care Economics
}

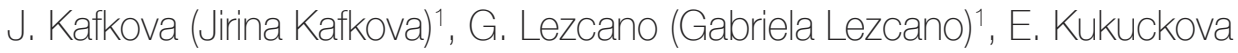 \\ (Eva Kukuckova) $^{1}$, M. Palenikova (Milica Palenikova) ${ }^{2}$
}

${ }^{1}$ UNHCR and St. John Neumann College Pribram, Czech Republic in Freetown, SL.

${ }^{2}$ St. John Paul II School of Missionary, Centre de Societe Bois Lorain Haiti,

SEU Tropical Program, HT.

\section{E-mail address:}

jirina.kafkova@icloud.com

\section{Reprint address:}

Jirina Kafkova

UNHCR and St. John Neumann College Pribram, Czech Republic in Freetown

Freetown

Siera Leone

Source: Clinical Social Work and Health Intervention

Pages: $25-27$

Volume: 11

Issue: 2

\section{Reviewers:}

Claus Muss

IGAP, Vienna, Austria

Mageswaari Rajoo

Kuala Lumpur, Malaysia

\section{Keywords:}

Global Health Economics.

\section{Publisher:}

International Society of Applied Preventive Medicine i-gap

CSWHI 2020; 11(2): 25 - 27; DOI: 10.22359/cswhi_11_2_05 (C) Clinical Social Work and Health Intervention

\section{Abstract:}

Cited references: 5 


\section{Introduction}

Global climate change is characterized by global warming and subsequent climate related natural catastrophes which are secondary and partially anthropic (rainforest change in Amazon; extensive drought in the Sahel regions of Africa; floods due to hurricanes in Caribbean; typhoons in SE Asia). Those climate changes are related to a re-emergence of new zoonotic pathogens from the tropics and subtropics and the mild climates of Europe, USA and Mainland China. (1-5)

\section{Example of climate related zoonotics}

\section{Zika, chikungunya and dengue invasion into Europe}

The spread of Zika and chikungunya caused huge economic losses for the organizers of Olympic; Paralympic; Asia Pacific Games; World Championship of Samba; and Carnival in Brasilia, Singapore, India and Pacific Islands. However, due to the vector (same for all three viruses/diseases - Aedes Aegypti and Aedes Albopictus mosquitoes - those three diseases also invazded Europe; dengue in Madeira in 2017; chikungunya in Rimini in 2014; in Réunion and Marseille from 2010 to 2017 causing substantial economic losses to the tourist industries in Mediterranean Europe. $(1-3,5)$

\section{Leishmaniosis in the Balkans}

Leishmaniosis is endemic in North/Central Africa. However, global warming caused the emergence of the sand fly vector from North Africa to Turkey, Greece and the Balkans, including Croatia, Albania, Bosna and Kosovo where the incidence of both visceral and cutamon leishmaniosis in appeared in Mediterranean tourists resorts. (2-5)

\section{Malaria in Greece}

In recent years (2015-2018) small epidemics of Maleria Parasites Plasmodiumalciparum a and Plasmodium vivax have been observed in the Athica Province in Greece and southern Sicily. The vector emerged probably through migration of birds (annual migration) from the Nile Delta. (1-5)

\section{Coronavirus COVID-19 and avian influenza}

At least 5 outbreaks of Avian flu and COVID19 in China and EU, UK and USA (2020) caused great economic losses. Avian has been reflected with the route of migrating birds from the Nile Delta to Balaton Lake and Neusiedler Lake in Hungary, Austria and Slovakia, on their routes to the countries of the thousands lakes (Finland, Poland). Fortunately, no (yet) cases of bird to human influenza have occurred. Coronavirus (flu bats, snakes etc.) devastated mainland China, Iran, Italy etc. in early 2020. (2-5)

\section{Conclusion}

Global climate changes also have caused an increase of vector born communicable (infects) diseases with global health consequences and extensive financial losses not only to health care, but to global economies in developed high-income regions (EU, USA).

\section{References:}

1. KIMULI D, KOMLOSI M, SABO I, BAUER F, KARVAJ M, OTRUBOVA J, JANCOVIC $\mathrm{M}$, JANKECHOVA M, PAUEROVA $\mathrm{K}$, POLONOVA K, MATEICKA F, BARTKOVJAK M, MIKOLASOVA G, SMREKOVA E, BENCA J, DURCOVA B, DORKO D, BEDNARIKOVA M, SCHIFFERDECKEROVA M, BARKASI D, OKOTH V, MULERA M (2019) Highlands malaria among internally displaced refugees in mountain areas of Kenya, Rwanda and Burundi. Lek Obz(Med Horizon)68.2019,5-6,149-150.

2. SHAHUM A, MIKOLASOVA G, KALAVSKA A et al. (2014) Am, J Trop Med Publ Health.55, 2014, S1,144.

3. HAJ ALI P, PUTEKOVA S, KABATOVA J, MARTIKOVA J, ZOLLEROVA K, BUCKO L, RADKOVA, VLCEK R, GREY E, OLAH M, DURICOVA Z, SVITEK R, SIMONEK T, OTRUBOVA J, BIBZA M, KOLIBAB M, MAMOVA A, PALENIKOVA M, MURGOVA A, TKACOVA L, KALATOVA D, JANKECHOVA M, BYDZOVSKY J, KHALIL I, MICHALIKOVA L, MRAZOVA M, LISKOVA A, HERDICS G, CARNECKY M, KHALED I (2016) Are Migrants From Middle East Carriers of Resistant Bacteria. Clin Soc Work \& Health Intervention 7. 2016. 3,9-14.

4. SHAHUM A, SLADECKOVA V, BENCA J, DUDOVA Z, MIKLOSKOVA M, BIELOVA M (2017) Respiratory islolates from the 
Orphanage in Phnompenh.,Clin Soc Work Health Intervention, $8.2017,1,17$.

5. WORLD HEALTH ORGANISATION
(WHO) GENEVE: CORONAVIRUS COV-19 UPDATE (10.3.2020) www.who.org /10.3. 2020. 